\title{
Pengaruh Model Pembelajaran Inkuiri Terbimbing terhadap Kemampuan Berpikir Kritis Siswa Kelas XI MIPA 3 SMA Negeri 11 Samarinda
}

\author{
Mayssy Safitri ${ }^{1 *}$, Zeni Haryanto ${ }^{2}$, dan Shelly Efwinda ${ }^{3}$ \\ 1,2,3 Program Studi Pendidikan Fisika Fakultas Keguruan dan IImu Pendidikan \\ Universitas Mulawarman, Samarinda-Indonesia \\ *E-mail: mayssy18@gmail.com
}

\begin{abstract}
Abstrak
Penelitian ini bertujuan untuk mengetahui pengaruh model pembelajaran inkuiri terbimbing terhadap kemampuan berpikir kritis siswa. Populasi penelitian ini adalah siswa kelas XI SMA Negeri 11 Samarinda. Teknik pengambilan sampel yang digunakan adalah purposive sampling. Sampel yang terpilih adalah kelas $\mathrm{X}$ MIPA 3 dengan jumlah 35 siswa. Penelitian ini mengaplikasikan pendekatan penelitian kuantitatif dengan metode quasi eksprimen dengan disain one group pretest-posttest. Tes tertulis berupa 10 buah soal essay digunakan untuk mengukur kemampuan berpikir kritis pada materi suhu dan kalor. Berdasarkan analisis data diperoleh rata-rata pre-test sebesar 30,11 yang termasuk kategori tidak kritis dan rata-rata post-test sebesar 76,62 yang termasuk kategori kritis. Rata-rata N-Gain pada indikator berpikir kritis adalah 0,67 yang termasuk kategori sedang. Berdasarkan hasil analisis uji-t berpasangan ditemukan bahwa terdapat perbedaan signifikan hasil pre-test dengan post-test. Dengan demikian, dapat disimpulkan bahwa terdapat pengaruh model pembelajaran inkuiri terbimbing terhadap kemampuan berpikir kritis siswa kelas XI MIPA SMA Negeri 11 Samarinda.
\end{abstract}

Kata kunci: Model Pembelajaran Inkuiri Terbimbing, Kemampuan Berpikir Kritis, Fisika, Suhu dan Kalor

\begin{abstract}
This study aims to determine the effect of guided inquiry learning models on students' critical thinking skills. The population of this research is the elevent-grade students of SMA Negeri 11 Samarinda. The sampling technique used was purposive sampling. The selected sample is class XI MIPA 3 with a total of 35 students. This study applies a quantitative research approach to the quasi-experimental method with one group pretest-posttest design. Written tests in the form of 10 essay questions were used to measure critical thinking skills on temperature and heat subject matter. Based on data analysis, the average pre-test was 30.11 which included in the uncritical category and the average post-test was 76.62 which was included in the critical category. The average $\mathrm{N}$-gain in the indicator of critical thinking is 0.67 which included in the medium category. Based on the result of the paired t-test analysis it was found that there is significant differences in the pre-test and post-test results. Thus, it can be concluded that there is an influence of guided inquiry learning models on the critical thinking skills of students of class XI MIPA of SMA Negeri 11 Samarinda.
\end{abstract}

Keywords: Guided Inquiry Learning, Critical Thinking Skills, Physic, Temperature and Heat

Article History: Received: 12 Desember 2019

Revised : 20 Januari 2020

Accepted: 14 Januari 2020

Published: 31 Januari 2020

How to cite: Safitri, M., Haryanto, Z., dan Efwinda, S. (2020). Pengaruh Model Pembelajaran Inkuiri Terbimbing Terhadap Kemampuan Berpikir Kritis Siswa Kelas XI MIPA 3 SMA Negeri 11 Samarinda, 1(1). pp. 19-26. Retrieved from http://jurnal.fkip.unmul.ac.id/index.php/jpfp/index

Copyright (c) Januari 2020, Jurnal Literasi Pendidikan Fisika 
Pengaruh Model Pembelajaran...

\section{PENDAHULUAN}

Pendidikan adalah proses manusia mengenali diri dengan potensi yang dimiliki, memahami apa yang sedang dipahami dan mampu menyelesaikan permasalahan dalam kehidupan tanpa harus kehilangan identitas dirinya. Pendidikan adalah suatu kebutuhan mendasar bagi setiap individu, seperti halnya dengan kebutuhan sandang, pangan dan papan. Pendidikan dapat dijadikan tolak ukur untuk mengetahui tingkat keberhasilan suatu negara. Pendidikan merupakan proses pembelajaran dimana peserta didik menerima dan memahami pengetahuan sebagai bagian dari dirinya, serta mengolahnya untuk kebaikan dan kemajuan bersama. Guru sebagai garda terdepan dalam mencetak pribadi yang unggul berprestasi dalam mencerdaskan bangsa memiliki peranan yang sangat penting. Berbagai masalah muncul khususnya dalam pendidikan indonesia, mulai dari sarana dan prasaran yang tidak memadai, kurang profesionalnya tenaga pendidik dan kurikulum yang selalu berubahubah (Sukma, Komariyah, \& Syam, 2016).

Bidang studi sains fisika sebagai bagian dari IImu Pengetahuan Alam merupakan objek mata pelajaran yang menarik dan memerlukan pemahaman dasar yang kuat. Pelajaran fisika lebih memfokuskan pada kemampuan peserta didik dalam menganalisis pengetahuan yang dimiliki dengan peristiwa atau gejala alam yang di alami pada kehidupan sehari-hari. Kajian fisika menuntut peserta didik mampu berpikir logis, kritis, kreatif, serta dapat beragumentasi secara benar. Namun kecenderungan pembelajaran fisika pada saat ini peserta didik hanya mempelajari fisika sebagai produk, menghafalkan konsep, teori dan hukum. Proses pembelajaran disekolah diharapkan dapat melatih peserta didik untuk berpikir kritis sebab melalui berpikir kritis peserta didik akan dilatih untuk mengamati keadaan, memunculkan pertanyaan, merumuskan hipotesis, mengobservasi dan mengumpulkan data kemudian memberikan kesimpulan. Berpikir kritis juga melatih siswa untuk berpikir logis dan tidak menerima sesuatu dengan mudah (Wahyuni, 2015).

Amin \& Jayanti (2018), menyatakan bahwa rendahnya hasil belajar fisika disebabkan oleh peserta didik tidak dibiasakan untuk mengembangkan potensi berpikirnya. Akibatnya pengetahuan yang diperoleh hanya bersifat sementara. Potensi yang dimaksud dalam hal ini adalah berpikir kritis. Berpikir kritis memungkinkan peserta didik untuk menganalisis pikirannya dalam menentukan pilihan dan menarik kesimpulan dengan cerdas. Kemampuan berpikir kritis merupkan kemampuan berpikir reflektif dan beralasan yang difokuskan pada pengambilan keputusan untuk memecahkan masalah. Dengan demikian, proses mental ini akan memunculkan kemampuan berpikir kritis peserta didik untuk menguasai konsep fisika secara mendalam.

Berdasarkan hasil pengamatan saat melakukan observasi di SMA Negeri 11 Samarinda dan wawancara dengan guru mata pelajaran fisika kelas XI MIPA diketahui bahwa nilai sebagian besar siswa pada pelajaran fisika hanya memenuhi standar KKM yang telah ditentukan oleh sekolah dan belum banyak siswa yang mampu melebihi standar KKM tersebut. Siswa juga masih kurang aktif bertanya meskipun sudah diberi kesempatan oleh guru bertanya pada saat proses pembelajaran berlangsung, pembelajaran masih terpusat pada guru sementara siswa menjadi pasif, rasa ingin tahu rendah, tidak ada gairah untuk memecahkan suatu permasalahan yang ditugaskan guru. Bahkan sebagian besar pula hanya dapat menyelesaikan soal-soal fisika yang sama persis dengan contoh yang diberikan oleh guru dan belum mampu menyelesaikan soal-soal yang bersifat analisis.

Berdasarkan pernyataan tersebut maka diperlukan adanya model pembelajaran yang sesuai untuk diterapkan dan dapat menggali kemampuan berpikir kritis. Salah satu model pembelajaran yang memperdayakan sains sebagai proses terutama demi meningkatkan kemampuan bepikir kritis siswa yaitu model pembelajaran inkuiri terbimbing. Model pembelajaran inkuiri terbimbing bertujuan untuk melatih siswa agar memiliki kecakapan intelektual (kecakapan berpikir), sehingga siswa dituntut untuk berperan aktif pada saat proses pembelajaran. Model pembelajaran inkuiri terbimbing merupakan model yang melibatkan 
Pengaruh Model Pembelajaran...

seluruh kemampuan siswa secara maksimal untuk mencari dan menyelidiki peristiwa atau fenomena-fenomena yang ada secara sistematis, kritis, logis, sehingga siswa dapat merumuskan sendiri penemuannya. Selain itu tingkat pemahaman yang diperoleh siswa langsung dalam proses menemukan jawaban terhadap persoalan yang ada dan langsung mempraktekkannya (Amijaya, Ramdani, \& Metra, 2018).

Pembelajaran inkuiri terbimbing cocok diterapkan dalam pembelajaran fisika karena pembelajaran fisika tidak hanya mempelajari prinsip, hukum, dan konsep namun diberikan aplikasi-aplikasi yang dapat mereka kembangkan untuk kemajuan teknologi (Purwandari \& Sunarno, 2017).

(Wahyuni, 2015) menyatakan bahwa pada model pembelajaran inkuiri terbimbing ada beberapa tahapan yaitu menyajikan masalah, membuat hipotesis, merancang percobaan, melakukan percobaan, mengumpulkan dan menganalisis data, serta memberikan kesimpulan dan mengkomunikasikan. Dalam model inkuiri terbimbing aktifitas pendidik bukanlah mentransfer ilmu tetapi menjadi fasilitator, membimbing dan mengarahkan siswa untuk menemukan konsep sendiri. Sehingga dalam pembelajaran inkuiri terbimbing siswa didorong lebih aktif dalam belajar agar kemampuan berpikir kritis siswa dapat dikembangkan.

Dari latar belakang uraian diatas, peneliti bermaksud untuk melakukan penelitian dengan judul "Pengaruh Model Pembelajaran Inkuiri Terbimbing Terhadap Kemampuan Berpikir Kritis Siswa Kelas XI SMA Negeri 11 Samarinda (materi Suhu dan Kalor)".

\section{METODE}

Pada penelitian ini jenis penelitian yang digunakan adalah penelitian kuantitatif. Metode yang dilakukan menggunakan metode eksperimen semu (Quasy experiment). Desain penelitian yang digunakan adalah One-Groupe Pretest-Posttest Design. Pada desain ini terdapat pretest, sebelum diberi perlakuan. Dengan demikian hasil perlakuan dapat diketahui lebih akurat, karena dapat membandingkan dengan keadaan sebelum diberi perlakuan. Setelah diberi perlakuan selama 4 kali pertemuan, sampel diberi posttest dengan instrument soal yang mengacu pada indikator berpikir kritis.

Penelitian ini dilakukan pada bulan juli hingga agustus di SMA Negeri 11 Samarinda, yang beralamatkan di Jl. Pelita Kec. Sambutan, Samarinda. Populasi pada penelitian ini meliputi seluruh siswa kelas XI SMA Negeri 11 Samarinda. Sampel yang digunakan adalah kelas XI MIPA 3 dengan teknik pengambilan sampel yaitu purposive sampling, dengan pertimbangan yang menyebabkan dipilihnya kelas XI MIPA 3 sebagai sampel karena kelas ini memiliki rata-rata kemampuan kognitif yang sama. Dalam penelitian ini teknik pengumpulan data yang digunakan adalah tes tertulis berupa pre-test dan post-test yang dilakukan pada akhir pembelajaran suhu dan kalor. Soal pre-test dan post-test berbentuk essay (uraian) sebanyak 10 soal, yang mengacu pada indikator kemampuan berpikir kritis yaitu Elementary clarification, Basic support, Inference, Advance clarification dan Strategy and tactic

Teknik analisis data yang digunakan pada penelitian ini yaitu analisis $\mathrm{N}$-Gain untuk mengetahui peningkatan pada pre-test dan post-test. Pengujian hipotesis menggunakan uji$\mathrm{t}$ berpasangan untuk mengatuhui ada tidaknya pengaruh yang dilihat dari perbedaan hasil pretest dan post-test sebelum dan sesudah diberikan model pembelajaran inkuiri terbimbing. Sebelum dilakukan uji-t berpasangan terlebih dahulu dilakukan uji normalitas untuk mengetahui data yang diperoleh apakah berdistribusi normal atau tidak dengan menggunakan SPSS 23 for windows.

\section{HASIL DAN PEMBAHASAN}

\section{HASIL}

Hasil rata-rata pretest sebelum diterapkan model pembelajaran inkuiri terbimbing dapat dilihat pada Tabel 1 berikut :

Tabel 1. Interpretasi Nilai Pre-test Kemampuan Berpikir Kritis Siswa Kelas XI MIPA 3 SMAN 11 Samarinda

\begin{tabular}{cccc}
\hline \multirow{2}{*}{ Nilai } & Kualifikasi & \multicolumn{2}{c}{ Tes Awal (Pre-test) } \\
\cline { 3 - 4 } & $\begin{array}{c}\text { Jumlah } \\
\text { Siswa }\end{array}$ & Persentase \\
\hline $80-100$ & Sangat Baik & 0 & $0 \%$ \\
\hline $70-79$ & Baik & 0 & $0 \%$ \\
\hline
\end{tabular}


Pengaruh Model Pembelajaran...

\begin{tabular}{cccc}
\hline $50-69$ & Cukup & 0 & $0 \%$ \\
\hline $40-49$ & Kurang & 7 & $20.00 \%$ \\
\hline $0-39$ & Sangat Kurang & 28 & $80.00 \%$ \\
\hline
\end{tabular}

Berdasarkan hasil perhitungan tersebut maka rata-rata kemampuan berpikir kritis siswa dapat ditunjukkan dalam bentuk grafik yang ditampilkan dalam Gambar 1 berikut:

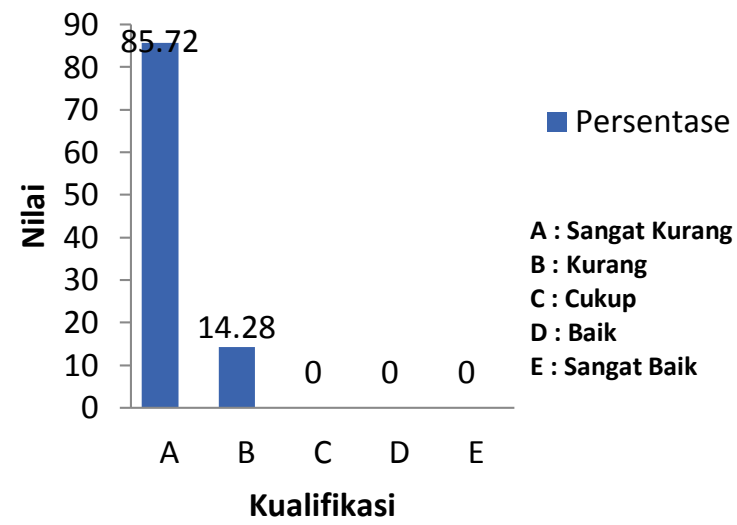

Gambar 1. Rata-rata pre-test kemampuan berpikir kritis siswa

Hasil rata-rata perolehan nilai post-test setelah diberikan model pembelajaran inkuiri terbimbing dapat dilihat pada Tabel 2 berikut:

Tabel 2. Interpretasi Nilai Post-test Kemampuan

Berpikir Kritis Siswa Kelas XI MIPA 3 SMAN 11

Samarinda

\begin{tabular}{cccc}
\hline \multirow{2}{*}{ Nilai } & Kualifikasi & \multicolumn{2}{c}{ Tes Awal (Pre-test) } \\
\cline { 3 - 4 } & $\begin{array}{c}\text { Jumlah } \\
\text { Siswa }\end{array}$ & Persentase \\
\hline $80-100$ & Sangat Baik & 9 & $25,72 \%$ \\
\hline $70-79$ & Baik & 21 & $60,00 \%$ \\
\hline $50-69$ & Cukup & 5 & $14,28 \%$ \\
\hline $40-49$ & Kurang & 0 & $0 \%$ \\
\hline $0-39$ & Sangat Kurang & 0 & $0 \%$ \\
\hline
\end{tabular}

Berdasarkan hasil perhitungan tersebut maka rata-rata kemampuan berpikir kritis siswa dapat ditunjukkan dalam bentuk grafik yang ditampilkan dalam Gambar 2 berikut:

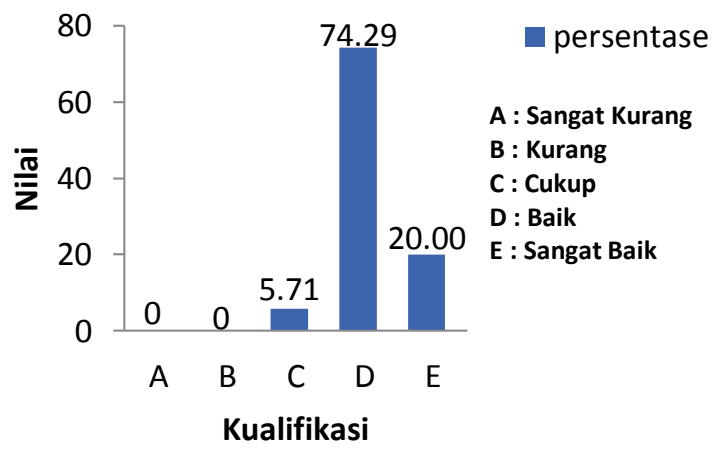

Gambar 2. Grafik Rata-Rata Post-test Kemampuan Berpikir Kritis Siswa

Peningkatan hasil pre-test dan post-test dapat di identifikasi dengan mencari $\mathrm{N}$-Gain nilai rata-rata siswa pada pokok bahasan materi Suhu dan Kalor yang dapat dilihat pada Tabel 3 sebagai berikut:

Tabel 3. Nilai $N$-Gain rata-rata siswa kelas XI MIPA3

\begin{tabular}{llllll}
\hline $\begin{array}{l}\text { Pre- } \\
\text { test }\end{array}$ & Kriteria & $\begin{array}{l}\text { Post- } \\
\text { test }\end{array}$ & Kriteria & N-Gain & Kriteria \\
\hline 30,11 & $\begin{array}{l}\text { Tidak } \\
\text { Kritis }\end{array}$ & 76,62 & Kritis & 0,67 & Sedang \\
\hline
\end{tabular}

Bila digambarkan dalam grafik perolehan kenaikan kemampuan berpikir kritis siswa adalah sebagai berikut:

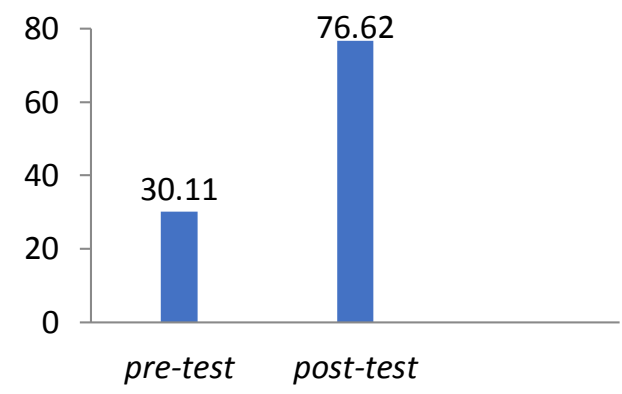

Gambar 3. Peningkatan Kemampuan Berpikir Kritis Siswa

Perolehan peningkatan kemampuan berpikir kritis setiap indikator dengan menerapkan model pembelajaran inkuiri terbimbing dapat dilihat pada Tabel 4 berikut:

Tabel 4. Perolehan N-Gain dari Tiap Indikator Kemampuan Berpikir Kritis

\begin{tabular}{|c|c|c|c|c|}
\hline \multirow[b]{2}{*}{ Indikator } & \multicolumn{2}{|c|}{ Rata-rata } & \multirow[b]{2}{*}{ N-Gain } & \multirow[b]{2}{*}{ Kriteria } \\
\hline & $\begin{array}{l}\text { Pre- } \\
\text { test }\end{array}$ & $\begin{array}{c}\text { Post- } \\
\text { test }\end{array}$ & & \\
\hline $\begin{array}{l}\text { Elementary } \\
\text { Clarification }\end{array}$ & 2,10 & 3,90 & 0,64 & Sedang \\
\hline $\begin{array}{l}\text { Basic } \\
\text { Support }\end{array}$ & 1,20 & 3,54 & 0,58 & Sedang \\
\hline Inference & 1,70 & 3,50 & 0,54 & Sedang \\
\hline $\begin{array}{c}\text { Advance } \\
\text { Clarification }\end{array}$ & 1,69 & 4,29 & 0,78 & Tinggi \\
\hline $\begin{array}{c}\text { Strategy } \\
\text { and Tactics }\end{array}$ & 0,46 & 4,16 & 0,82 & Tinggi \\
\hline
\end{tabular}

Bila digambarkan dalam bentuk grafik perolehan kenaikan dari tiap indikator berpikir kritis yaitu sebagai berikut: 
Pengaruh Model Pembelajaran...

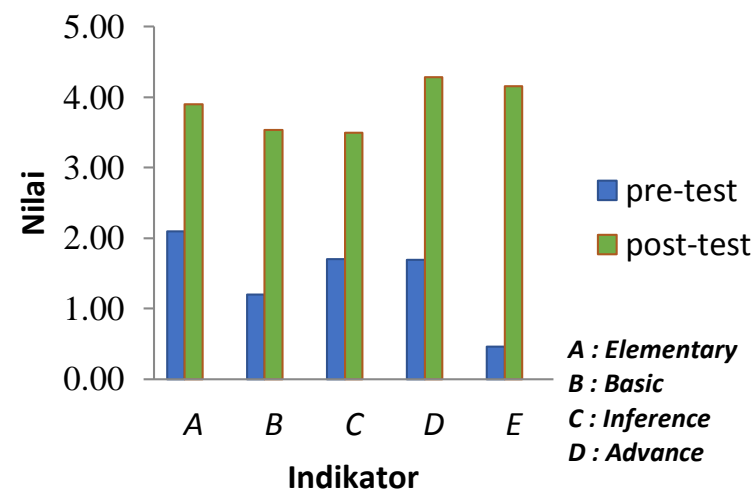

Gambar 4. Grafik Peningkatan Rata-Rata Skor Tiap Indikator Pre-test dan Post-test Kemampuan Berpikir Kritis Siswa

Untuk melihat persentase dari $N$-Gain ratarata siswa kelas XI MIPA 3 SMAN 11 Samarinda dapat dilihat pada Tabel 5 sebagai berikut:

Tabel 5. Persentase Nilai N-Gain Rata-Rata Siswa

\begin{tabular}{cccc}
\hline Nilai & Kategori & $\begin{array}{c}\text { Jumlah } \\
\text { Siswa }\end{array}$ & Persentase \\
\hline $\mathrm{g} \geq 0,7$ & Tinggi & 11 & $31 \%$ \\
$0,3 \leq \mathrm{g}<0,7$ & Sedang & 24 & $69 \%$ \\
$0 \leq \mathrm{g} \leq 0,3$ & Rendah & 0 & $0 \%$ \\
\hline
\end{tabular}

Persentase skor N-Gain siswa kelas XI MIPA 3 SMAN 11 Samarinda berdasarkan analisis data diatas maka dapat disajikan dalam bentuk grafik sebagai berikut:

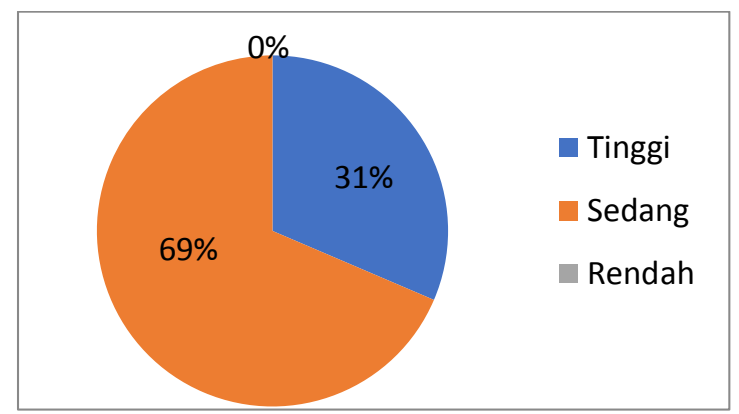

Gambar 5. Grafik Persentase Nilai Rata-Rata N-Gain Siswa

Hasil uji normalitas data pre-test dan posttest menggunakan metode Shapiro Wilk dengan bantuan software SPSS 23.0 for Windows didapatkan hasil signifikasi pre-test dan post-test masing-masing 0,065 dan 0,075.

Selanjutnya dilakukan analisis uji-t berpasangan data pre-test dan post-test dilakukan untuk mengetahui ada tidaknya perbedaan pre-test dan post-test dengan bantuan software SPSS 23.0 for Windows dapat dilihat pada Tabel 6 berikut:

Tabel 6. Hasil Analisis Uji-t

Paired Samples Test

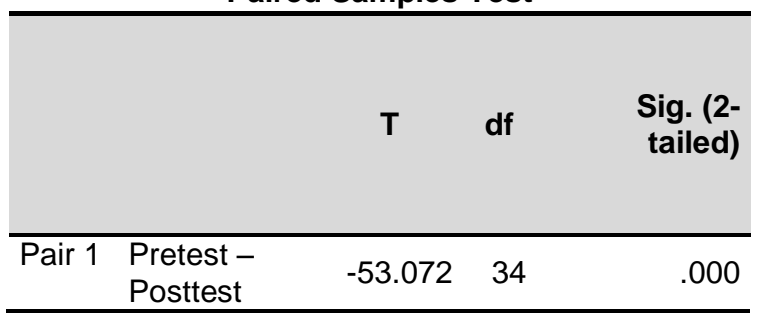

\section{PEMBAHASAN}

Penelitian ini bertujuan untuk mengetahui pengaruh model pembelajaran inkuiri terbimbing terhadap kemampuan berpikir kritis siswa kelas XI MIPA 3 SMA Negeri 11 Samarinda Tahun Ajaran 2019/2020. Berdasarkan hasil analisis data penelitian sebelum siswa diajar menggunakan model pembelajaran inkuiri terbimbing, pada Tabel 1 diperoleh bahwa ratarata pre-test sebesar 30,11 dengan kategori tidak kritis atau tidak tuntas, Hal ini menunjukkan bahwa kemampuan awal siswa sebelum diberikan pembelajaran dengan menggunakan model pembelajaran inkuiri terbimbing relatif rendah karena siswa masih terbiasa dengan menggunakan model pembelajaran konvensional. Sedangkan pada hasil nilai post-test yang dapat dilihat pada Tabel 2 diperoleh nilai rata-rata sebesar 76,62 yang termasuk dalam kategori kritis atau tuntas. Sehingga ketuntasan belajar dari nilai post-test terdapat 24 siswa yang tuntas mencapai nilai KKM, menurut penulis 24 siswa yang tuntas ini dikarenakan pada saat dilakukan kegiatan belajar mengajar mereka terlihat aktif dan memperhatikan apa yang dijelaskan oleh penulis pada saat menjelaskan materi yang diajarkan, sedangkan 9 siswa yang tidak tuntas atau tidak mencapai nilai KKM, dikarenakan mereka jarang masuk dalam kelas sehingga ketinggalan materi dan adapula yang hanya bercanda tidak memperhatikan materi yang disampaikan.

Peningkatan kemampuan berpikir kritis siswa menggunakan pre-test dan post-test yang dapat dilihat pada Tabel 3, yang dianalisis melalui Normalizad-Gain ( $N$-Gain). Setelah dilakukan pembelajaran menggunakan model 
Pengaruh Model Pembelajaran...

pembelajaran inkuiri terbimbing terdapat peningkatan nilai berdasarkan $\mathrm{N}$-Gain dengan nilai rata-rata sebesar 0,67 yang termasuk dalam kategori sedang. Hal ini dapat dilihat bahwa semakin sering dan menarik menerapkan model pembelajaran inkuiri terbimbing maka akan semakin meningkat pada kemauan belajar siswa sehingga rasa ingin tahu siswa akan lebih meningkat pada materi yang diajarkan dan hasil belajar siswapun akan semakin baik, dan tidak dipungkiri kemampuan berpikir kritis siswa juga akan mengalami peningkatan.

Berdasarkan indikator penilaian kemampuan berpikir kritis yang dapat dilihat pada Tabel 4, pada indikator Elementary clarification (memberikan penjelasan dasar) diperoleh nilai rata-rata pre-test sebesar 2,10 dan nilai ratarata post-test sebesar 3,90 dengan N-Gain 0,64 yang termasuk dalam kategori sedang, hal ini disebabkan pada indikator ini ada beberapa siswa yang belum dapat mengidentifikasi dan mempertimbangkan jawaban yang mungkin serta mengaitkannya dengan konsep fisika pada materi suhu dan kalor.

Pada indikator Bassic support (membangun keterampilan dasar) diperoleh nilai rata-rata pretest sebesar 1,20 dan rata-rata nilai post-test sebesar 3,54 dengan $N$-Gain 0,58 yang termasuk dalam kategori sedang, hal ini disebabkan masih terdapat sebagian siswa yang belum bisa untuk mempertimbangkan jawaban yang memungkinkan dari sumber yang ada dan siswa masih ragu-ragu dalam menjawab soal yang diberikan.

Indikator Inference (menyimpulkan) diperoleh nilai rata-rata pre-test sebesar 1,70 dan nilai rata-rata post-test sebesar 3,50 dengan $\mathrm{N}$-Gain 0,54 yang termasuk dalam kategori sedang, hal ini disebabkan pada saat mengerjakan soal masih banyak siswa yang tidak dapat menyimpulkan dari soal tersebut.

Indikator Advance clarification (memberikan penjelasan lanjut) diperoleh nilai rata-rata pretest sebesar 1,69 dan nilai rata-rata post-test sebesar 4,29 dengan 0,78 yang termasuk dalam kategori tinggi, hal ini disebabkan siswa sudah bisa untuk mendefinisikan istilah dan memberikan penjelasan lebih lanjut dari soal yang diberikan dan menghubungkan konsep dari materi yang sudah diajarkan.

Indikator Strategy and tactics (mengatur strategi dan taktik) diperoleh nilai rata-rata pretest sebesar 0,46 dan nilai rata-rata post-test 4,16 dengan $\mathrm{N}$-Gain 0,82 yang termasuk dalam kategori tinggi dan indikator ini merupakan indikator yang peningkatannya paling tinggi diantara indikator yang lain hal ini disebabkan pada indikator ini siswa dapat memecahkan permasalahan yang terdapat pada soal yang berupa soal hitungan dengan berbekal pengetahuan dari rumus-rumus yang telah diberikan sebelumnya pada saat pembelajaran.

Sesuai dengan perhitungan pada Tabel 5 yang menunjukkan kenaikan $\mathrm{N}$-Gain terhadap kemampuan berpikir kritis berdasarkan nilai pretest dan post-test. Dari hasil tersebut, dapat dilihat bahwa model pembelajaran inkuiri terbimbing dapat meningkatkan kemampuan berpikir kritis siswa karena model ini menekankan pada aktivitas siswa secara maksimal untuk mencari dan menemukan artinya siswa sebagai subjek belajar. Jadi, pada model ini siswa tidak hanya mendengarkan tetapi terlibat langsung dalam hal menemukan dan memecahkan permasalahan yang diberikan.

Data yang diperoleh dianalisis menggunakan uji normalitas untuk mengetahui apakah data yang diperoleh berdistribusi normal atau tidak. Hasil uji normalitas pada pre-test dan post-test tersebut menunjukkan nilai $p$-value masingmasing sebesar 0,065 dan 0,075 , sehingga dapat disimpulkan data peningkatan kemampuan berpikir kritis siswa terdistribusi dengan normal karena lebih dari 0,05.

Setelah data terdistribusi normal kemudian dilakukan pengujian hipotesis dengan analisis Uji-t berpasangan dalam penelitian ini untuk mengetahui ada tidaknya pengaruh sebelum dilakukan pembelajaran model Inkuiri Terbimbing dan sesudah diberikan model pembelajaran Inkuiri Terbimbing pada kemampuan berpikir kritis siswa kelas XI MIPA 3 SMA Negeri 11 Samarinda yang dilihat dari perbedaan hasil pre-test dan post-test pada Tabel 6. Hasil analisis data dengan model pembelajaran inkuiri terbimbing ternyata menghasilkan nilai pre-test dan post-test yang 
Pengaruh Model Pembelajaran...

signifikan yaitu 0.000 . Perhitungan tes nilai ratarata pre-test dan post-test menunjukkan harga thitung sebesar 53.072, sedangkan untuk harga t-tabel $d f=34$ dengan taraf signifikan 0,05 adalah sebesar 1,69092 untuk kemampuan berpikir kritis. Harga t-hitung yang lebih besar dari t-tabel menyebabkan $\mathrm{H}_{a}$ diterima dan $\mathrm{H}_{0}$ ditolak. Berdasarkan analisis tersebut, telah terbukti bahwa terdapat perbedaan yang signifikan antara hasil rata-rata pre-test dan post-test kemampuan berpikir kritis siswa setelah diberikan perlakuan berupa model pembelajaran inkuiri terbimbing, yang artinya terdapat pengaruh yang signifikan pada model pembelajaran inkuiri terbimbing terhadap kemampuan berpikir kritis siswa. Terlihat bahwa model pembelajaran inkuiri terbimbing yang didapatkan siswa selama melakukan pembelajaran dengan mengerjakan lembar kerja dan pengamatan langsung dapat meningkatkan kemampuan berpikir kritis siswa kelas XI MIPA 3 SMA Negeri 11 Samarinda pada materi suhu dan kalor, hal ini disebabkan melalui model inkuiri terbimbing siswa dilatih menggunakan segala potensinya terutama proses mentalnya untuk menemukan sendiri konsep-konsep atau prinsip-prinsip pembelajaran fisika sehingga keaktifan siswa dalam pembelajaran fisika untuk mengembangkan kemampuan berpikir kritis siswa meningkat.

Hal ini sesuai dengan hasil penelitian yang dilakukan oleh Priono (2015) menunjukkan bahwa rata-rata capaian kemampuan berpikir kritis siswa meningkat melalui penerapan inkuiri terbimbing. Hal ini terjadi karena melalui pembelajaran inkuiri terbimbing guru mengajak siswa terlibat aktif dalam pembelajaran. Siswa diajak aktif berpikir mengenali masalah, mengungkapkan gagasan-gagasan pemecahan masalah, merancang percobaan sendiri untuk menjawab masalah yang dihadapi, melakukan percobaan untuk menemukan jawaban, serta mendiskusikan hasilnya sampai pada penyususan kesimpulan.

\section{PENUTUP}

Berdasarkan hasil penelitian dan analisis data yang telah dilakukan di SMA Negeri 11
Samarinda kelas XI MIPA 3 dapat disimpulkan bahwa, terdapat perbedaan yang signifikan pada hasil pre-test dan post-test, sehingga terdapat pengaruh pada model pembelajaran inkuiri terbimbing terhadap kemampuan berpikir kritis siswa pada materi suhu dan kalor.

Adapun saran yang dapat penulis berikan adalah sebagai berikut: (1) bagi peserta didik agar terus belajar dan berlatih serta meningkatkan belajarnya, sehingga mempunyai kemampuan berpikir kritis yang tinggi dan baik dalam mengatasi permasalahan dalam pembelajaran, (2) bagi guru, dapat menerapkan atau memperkenalkan siswa model pembelajaran yang baru dan berbeda agar tercipta suasana belajar yang menyenangkan sehingga siswa dapat mengembangkan kemampuan berpikir mereka untuk mengatasi permasalahan atau persoalan dalam belajar, (3) bagi sekolah, agar dapat meningkatkan fasilitas yang sudah ada agar proses belajar mengajar dikelas bisa lebih baik lagi, (4) bagi peneliti selanjutnya, penulis mengharapkan skripsi ini dapat digunakan sebagai referensi untuk melanjutkan penelitian berikutnya agar lebih bermanfaat untuk dunia pendidikan, dapat juga divariasikan dengan mengubah model pembelajaran ataupun materi pembelajaran yang digunakan.

\section{DAFTAR PUSTAKA}

Amijaya S.L,. Ramdani, A., \& Merta, W. (2018). Pengaruh Model Pembelajaran Inkuiri Terbimbing Terhadap Hasil Belajar dan Kemampuan Berpikir Kritis Peserta didik. Jurnal Pijar MIPA, 13(2), 94-99.

Amin, D.B., \& Jayanti, A. (2018) . Pengaruh Pembelajaran Inkuiri Terbimbing Terhadap Kemampuan Berpikir Kritis Peserta Didik Kelas XI MIA SMA Negeri 2 Barru. Jurnal Sains dan Pendidikan Fisika (JSPF), 14(1),23-28.

Priono, A. (2015). Penerapan Model Pembelajaran Inkuiri Terbimbing Untuk Meningkatkan Kemampuan Berpikir Kritis Siswa Kelas XI SMA Negeri Lubung Lingau Tahun Ajaran 2014/2015. Skripsi tidak dipublikasikan. STKIP-PGRI Lubuk Lingau. 
Purwandari dan Sunarno, W. (2017).

Pembelajaran Fisika Menggunakan Inkuiri Terbimbing Dengan Metode Eksperimen dan Proyek Ditinjau Dari Kreativitas dan Kemampuan Berpikir Kritis Siswa. Momentum: Physics Education Journal, 6(3), 39-46.

Sukma, Komariyah L., dan Syam M. (2016). Pengaruh Model Pembelajaran Inkuiri Terbimbing (Guided Inquiry) dan Motivasi Terhadap Hasil Belajar Fisika Siswa. Santifika: Jurnal IImu Pendidikan MIPA dan MIPA, 18(1), 59-63.

Wahyuni, S. (2015). Pengembangan Bahan ajar IPA Untuk Meningkatkan Kemampuan Berpikir Kritis Siswa SMP. Jurnal Materi dan Pembelajaran Fisika (JMPF), 6(1), 4752. 